\title{
Helicobacter pylori virulence factors in gastric carcinogenesis
}

\author{
Sicheng Wen and Steven F. Moss \\ Department of Medicine, Division of Gastroenterology, Rhode Island Hospital and Brown University, \\ Providence, RI, USA
}

\begin{abstract}
Helicobacter pylori infection is the most important risk factor in the development of non-cardia gastric adenocarcinoma; host genetic variability and dietary co-factors also modulate risk. Because most $H$. pylori infections do not cause cancer, $H$. pylori heterogeneity has been investigated to identify possible virulence factors. The strongest candidates are genes within the cag (cytotoxin associated antigen) pathogenicity island, including the gene encoding the CagA protein, as well as polymorphic variation in the VacA vacuolating exotoxin and the blood group antigen binding adhesin BabA. Improved understanding of the pathogenesis of $\mathrm{H}$. pylori-associated gastric cancer may improve risk stratification for prevention and therapy.
\end{abstract}

\section{Keywords}

Gastric cancer; H. pylori; virulence factors; CagA; VacA

\section{Introduction}

The worldwide mortality from gastric cancer remains very high, especially in Asia and much of the developing world [1]. Although the incidence of this disease continues to slowly decline in the West, gastric cancer is currently the second most common cause of cancer death in the world [2] and the fifth most common cancer and the fourth leading cause of cancer-related death in Europe [3].

Helicobacter pylori (H. pylori) is a micro-aerophilic spiral-shaped Gram-negative bacterium that colonizes the stomach for almost the entire lifetime of the host. H. pylori infects more than half of the world's human population, and produces gastroduodenal diseases, such as peptic ulcer disease in about $10 \%$ and gastric adenocarcinoma in 1-2\% of those that it infects. It has been evident for over 20 years that $H$. pylori is involved in the development of gastric adenocarcinoma; in 1994, the WHO concluded that $H$. pylori is a definite or class I carcinogen in humans. Prospective studies reveal that the risk for development of gastric carcinoma is much greater in $\mathrm{H}$. pylori-infected populations than in uninfected populations [4]. In 2002, an estimated 1.9 million cases, or $17.8 \%$ of the worldwide incidence of cancer, were considered

(C) 2009 Elsevier Ireland Ltd. All rights reserved.

Address for reprints: Steven F. Moss, M.D., Gastroenterology Division, Rhode Island Hospital, 593 Eddy Street, APC 414, Providence, RI 02903. Email: Steven_Moss@Brown.edu.

Publisher's Disclaimer: This is a PDF file of an unedited manuscript that has been accepted for publication. As a service to our customers we are providing this early version of the manuscript. The manuscript will undergo copyediting, typesetting, and review of the resulting proof before it is published in its final citable form. Please note that during the production process errors may be discovered which could affect the content, and all legal disclaimers that apply to the journal pertain.

Conflicts of interest Statement

None Declared 
to be attributable to infectious diseases, with $\mathrm{H}$. pylori infection as the leading cause (5.5\% of all cancers), followed by human papilloma viruses, hepatitis B and C viruses, Epstein-Barr virus, human immunodeficiency virus, and human herpesvirus-8 [5]. H. pylori is responsible for about $75 \%$ of all noncardia gastric cancers and $63.4 \%$ of all stomach cancers worldwide [5].

Despite the close association of $H$. pylori infection with non-cardia gastric cancer, most infected persons do not develop the disease. The clinical outcome of $H$. pylori infection is determined by multiple factors, including host genetic predisposition (especially certain cytokine polymorphisms [6]), H. pylori strain heterogeneity and environmental factors such as dietary salt intake [7]. H. pylori is a highly heterogeneous bacterial species, both genotypically and phenotypically, and is highly adapted for survival in the gastric niche. The genomic diversity of $H$. pylori parallels that of its host species, consistent with colonization of the earliest humans and co-migration out of East Africa at least 60,000 years ago [8]. $H$. pylori heterogeneity and the association of certain $\mathrm{H}$. pylori products with specific diseases (virulence factors) has been intensively investigated over the past two decades since $H$. pylori was first cultured. In an attempt to bring order to a sometimes chaotic field, it has been proposed that for designation as virulence factor the following criteria should be met (1) the H. pylori determinant should have a disease or other in-vivo correlation, (2) there should be epidemiologic consistence across populations and regions, (3) there should be biologic plausibility, and (4) the biologic activity should be reduced or eliminated by gene deletion and restored by complementation [9]. With respect to gastric cancer, the major $H$. pylori candidate virulence factors include the cag pathogenicity island (PAI), the CagA protein, the vacuolating toxin VacA, the blood group antigen binding adhesin (BabA) and possibly the duodenal ulcer producing gene (dupA) (Figure 1). We shall review the association of these virulence factors with gastric cancer and discuss the possible underlying molecular mechanisms.

\section{Cytotoxin associated antigen (CagA)/cag pathogenicity island (cag PAl)}

The cag (cytotoxin-associated gene) pathogenicity island (cag PAI) is a 40 kilobase segment of DNA, containing 31 genes, many of which encode components of a type 4 bacterial secretion system $[10 ; 11 ; 12]$. The secretion system acts as a molecular syringe for delivery of bacterial products, including the cag gene product $\mathrm{CagA}$ and peptidoglycan component into eukaryotic cells $[13 ; 14]$. The cag PAI plays an important role in $H$. pylori pathogenesis, and is not expressed in all strains. Approximately $60 \%$ of $\mathrm{H}$. pylori strains isolated in Western countries carry the cag PAI, whereas almost all of the East Asian strains isolated are cag PAI-positive [15]. CagA is a 121-145 kDa immuno-dominant protein, encoded by one of the genes ( cagA) within the cag PAI. It is commonly used as a marker for the entire cag locus in epidemiological studies. In Western populations, cagA-positive strains are more commonly associated with peptic ulceration atrophic gastritis and gastric adenocarcinoma than $c a g A$ negative strains, $[16 ; 17 ; 18 ; 19]$ but this relationship is not observed in many high gastric cancer populations including East Asia where almost all strains are cag-positive.

More recent studies in animal and cell culture models indicate the likely role of CagA and the cag PAI in human gastric cancer associated with $H$. pylori infection [20;21;22;23]. Infection of gerbils with partially or completely disrupted cag $P A I$ strains results in significantly less gastric inflammation and fewer gastric ulcers compared with wild-type infections [20;24]. CagA deletion also prevents gastric carcinogenesis associated with $H$. pylori in the gerbil model [23]. Ohnishi et al recently provided the first direct evidence of the potential oncogenicity of CagA in vivo [25]. Transgenic expression of CagA in mice led to the development of gastric epithelial hyperplasia and adenocarcinomas of the stomach and small intestine. Interestingly, these effects were not seen with a transgene expressing a phosphorylation-resistant form of CagA (see section 2.3 below). However, the development of gastric cancer in the absence of 
inflammation and also its occurrence in non-gastric organs raises questions about the applicability of this model to humans. Nevertheless, these results provide strong evidence for CagA acting as a bacterium-derived oncoprotein in the development of $H$. pylori-associated neoplasms in an animal model.

\subsection{Delivery of CagA into gastric epithelial cells}

How does the translocation of the CagA protein into gastric epithelial cells by the type 4 secretion system promote cancer? Recent studies have shown that $\mathrm{CagF}$, a chaperone-like protein which interacts with the C-terminal secretion signal of CagA, is involved in the early steps of CagA recognition and is crucial for CagA delivery [26;27]. CagL, another product of a cag PAI protein-encoded gene, utilizes host integrin $\alpha_{5} \beta_{1}$ as a cell surface receptor. This CagL-integrin interaction then triggers CagA delivery into target cells and subsequently activates focal adhesion kinases (FAKs) and SRC kinases [28]. However, vector-expressed CagA alone undergoes efficient tyrosine phosphorylation when expressed in gastric epithelial cells [29], strongly suggesting that the CagL-integrin interaction is not an essential prerequisite for the tyrosine phosphorylation of CagA by host cell tyrosine kinases.

\subsection{Phosphorylated CagA and CagA phosphorylation-dependent effects}

Once injected into gastric epithelial cells, CagA can be tyrosine phosphorylated at its five amino-acid Glu-Pro-Ile-Tyr-Ala (EPIYA) repeat region [29]. This phosphorylation is initially mediated by SRC family tyrosine kinases (SFKs) and then continuously by the c-ABL kinase [30;31;32;33]. Tyrosine-phosphorylated CagA subsequently interacts with SRC homology (SH2) domain-containing host cell proteins, including the tyrosine phosphatase SHP-2, the Cterminal Src tyrosine kinase (CSK) and the adaptor protein CRK. This results in cytoskeletal reorganization and cell elongation - a phenotype that leads to cell scattering and the so-called "hummingbird" morphological change [29;34;35].

The hummingbird phenotype is a result of CagA-activated SHP-2 dephosphorylating FAK, thereby down-regulating FAK kinase activity and activation of ERK MAP kinases [36;37]. MAP kinase activation also promotes cell-cycle progression and this, together with the phenotypic changes induced, has been taken as evidence that CagA-activated SHP-2 may play an important role in cell transformation and gastric cancer promotion. Activation of CRK by CagA induces several downstream signaling pathways, such as SoS1/H-RAS/RAF1 and C3G/ RAP1/B-Raf, suggesting that CagA/CRK signaling is required for both $H$. pylori-induced cell scattering and cell-cell dissociation [35]. While most phosphorylated CagA interacts with SHP-2, some also interacts with CSK, through a tyrosine phosphorylation-dependent mechanism leading to the inhibition of SFK activity. This blocks CagA phosphorylation and subsequently attenuates excess CagA-SHP2 signaling [34] through negative feedback.

In addition to the presence or absence of the cag PAI, variations in the EPIYA repeat region of CagA have also been associated with $H$. pylori pathogenicity [38]. Four distinct types of EPIYA motif have been identified, termed, EPIYA-A through EPIYA-D [39;40]. CSK binds specifically to tyrosine phosphorylated EPIYA-A or EPIYA-B, whereas SHP2 specifically binds to tyrosine phosphorylated EPIYA-C or EPIYA-D [29;34]. CagA from H. pylori strains found in the Western world typically contain EPIYA-A, EPIYA-B and EPIYA-C in the Cterminal EPIYA repeat region. In contrast, East Asian forms of CagA also possess EPIYA-A and EPIYA-B but not the EPIYA-C variant; instead, they contain an East Asian CagA-specific EPIYA-D sequence. The EPIYA-D region of East Asian CagA shows stronger SHP2 binding activity and induces the hummingbird phenotype in cultivated gastric epithelial cells to a greater extent than that induced by the EPIYA-C segment of Western CagA [40]. The number of EPIYA-C or EPIYA-D segments region also directly correlates with higher levels of tyrosine phosphorylation, SHP2 binding activity and more induction of the hummingbird morphology, 
which may therefore explain why populations infected with East Asian CagA-positive $H$. pylori are at a greater risk for gastric cancer then those infected with Western-type CagApositive strains [41;42].

\subsection{Effects of CagA independent of CagA phosphorylation}

In addition to phosphorylation-dependent activities, $\mathrm{CagA}$ also perturbs cell functions in a tyrosine phosphorylation-independent manner. Nonphosphorylated CagA interacts with certain host cell proteins such as the epithelial tight junction-scaffolding protein zonulin (ZO-1) [43], the cell adhesion protein E-cadherin [22], the hepatocyte growth factor receptor c-Met [44], the cadherin-associated protein $\beta$-catenin [21], the adaptor protein GRB-2 [45] and the kinase PAR1 [46;47]. These CagA-host protein interactions disrupt tight and adherent junctions, leading to a loss of cell polarity, and inducing pro-inflammatory and mitogenic responses-effects that may be important in the development of gastric carcinoma.

Tight junctions play an important role in maintaining paracellular permeability and cell polarity, and are also involved in cell motility, cell-cell adhesion and cell proliferation. Independent of tyrosine phosphorylation, $\mathrm{CagA}$ interacts with and mediates recruitment of the scaffolding protein $\mathrm{ZO}-1$ and the tight-junction protein JAM to sites of bacterial attachment on host cell membranes, causing disruption of the assembly and function of both tight and adherent junction adhesion [43]. CagA also directly interacts with PAR1, a key regulator of cell polarity, and in turn inhibits PAR1 activity resulting in the loss of epithelial cell polarity [46;47]. As a result, the loss of cell polarity and disruption of cell adhesion induces transition from a polarized to an invasive phenotype in cultured epithelial cells [48]. CagA also interacts with E-cadherin independently of CagA tyrosine phosphorylation, leading to impairment of E-cadherin/ $\beta$-catenin complex and to cytoplasmic and nuclear accumulation of $\beta$-catenin. Downstream events include transcription of genes involved in intestinal differentiation such as $c d x l$, and the $т и с 2$ mucin gene, causing transdifferentiation from gastric to intestinal type epithelial cells [22]. These results suggest that the ability of CagA to induce destabilization of E-cadherin/ $\beta$-catenin complexes may contribute to the development of intestinal metaplasia, a precursor lesion in the histological progression from a normal to a neoplastic gastric mucosa.

In vitro, intracellular nonphosphorylated CagA also interacts with growth factor receptor GRB2, causing activation of the RAS/MEK/ERK pathway, resulting in increased cell scattering and proliferation [45]. CagA can also target the c-Met hepatocyte growth factor receptor and deregulate $\mathrm{c}-\mathrm{Met}$ receptor signaling leading to a motogenic response, again independent of CagA tyrosine phosphorylation [44].

In vivo, $H$. pylori infection is associated with the production of pro-inflammatory cytokines and chemokines, such as IL-8, that stimulate neutrophil infiltration into the gastric mucosa. Most studies demonstrate that the cag PAI, but not CagA itself, is essential for $\mathrm{H}$. pyloriinduced IL-8 expression [12;49;50]. However, some recent studies suggest that CagA may promote IL-8 release via a $\mathrm{RAS} \rightarrow \mathrm{RAF} \rightarrow \mathrm{MEK} \rightarrow \mathrm{ERK} \rightarrow \mathrm{NF}-\kappa \mathrm{B}$ signaling pathway independent of SHP-2- and c-Met [51]. CagA can also translocate nuclear factor of activated $\mathrm{T}$ cells (NFAT) from the cytoplasm to the nucleus in gastric epithelial cells. Translocation and activation of NFAT requires the EPIYA-containing region of CagA but is also independent of CagA phosphorylation [52]. Thus, CagA activates transcription factors such as NF- $\mathrm{KB}$, NFAF and TCF by MEK/ERK and Wnt/ $\beta$-catenin signaling pathway in a CagA tyrosine phosphorylation independent manner, resulting in the deregulation of many downstream genes including those encoding cytokines, anti-apoptotic proteins and metalloproteases [22;51;52].

The data from in vivo co-cultures indicate that following CagA injection into gastric epithelial cells by the type 4 secretory system, phosphorylated or nonphosphorylated CagA physically interacts with host cell proteins to trigger distinct signaling pathways. As a result, cells elongate, 
scatter and exhibit disturbances of cell junctions with loss of polarity. Other downstream events include pro-inflammatory gene expression and the deregulation of proliferation and apoptosis. These phenomena are consistent with an oncogenic role for CagA translocation in gastric carcinogenesis, but their significance remains uncertain until they can be confirmed to be relevant in vivo.

\section{Vacuolating cytotoxin (VacA)}

Another major $H$. pylori virulence determinant is the vacuolating cytotoxin, VacA, which induces cytoplasmic vacuolation in cultured epithelial cells. Unlike the cag PAI, the vacA gene is present in all strains. vacA encodes a large ( 140-kilodalton) preprotoxin, which includes an amino-terminal signal peptide and a carboxy-terminal domain. Following cleavage during secretion, toxin monomers of 88 kilodalton result [53;54]. The mature toxin subunits are released as soluble proteins into the extracellular space. They may also be retained on the surface of the bacterium [55], and they can aggregate into oligomeric complexes for insertion into lipid bilayers to form anion-selective channels [56].

Polymorphisms among the VacA alleles result in different levels of cytotoxicity. Variations in the signal (s) region and the mid (m) region greatly influence the effects of VacA [57]. Specifically, s region variation is associated with the vacuolating activity of VacA, [58] whereas the $\mathrm{m}$ region determines the cell specificity of vacuolation by affecting toxin binding to host cells [59;60]. All possible combinations from these regions have been identified and among them, vacuolating activity is highest in $\mathrm{s} 1 / \mathrm{m} 1$ strains, less in $\mathrm{s} 1 / \mathrm{m} 2$ strains and is absent in $H$. pylori expressing $\mathrm{s} 2 / \mathrm{m} 2$ forms [57]. VacA polymorphisms are correlated with gastric diseases, particularly peptic ulcer disease, in studies of Western populations. For example, VacA s1/m1may be strongly associated with duodenal and gastric ulcer disease and with gastric cancer [57;61;62]. However, East Asian strains are almost universally s1/m1 and are not associated with any specific clinical outcome.

Rhead et al recently identified a third polymorphic determinant of vacuolating activity in strains from Western populations that are located between the signal region and mid region, which they termed the intermediate (i) region [63]. In that report, two allelic variants of this region were denoted i1 (vacuolating) and i2 (nonvacuolating). All s1/m1 vacA alleles were of type $\mathrm{i} 1$, all s $2 / \mathrm{m} 2$ alleles were of type $\mathrm{i} 2$ and $\mathrm{s} 1 / \mathrm{m} 2$ alleles could be $\mathrm{i} 1$ or $\mathrm{i} 2$. In an Iranian population i1-type strains were strongly associated with gastric adenocarcinoma and of the three VacA polymorphic sites, the i1 genotype appeared to be a better predictor of carcinoma-associated $H$ pylori strains than s or $\mathrm{m}$ genotype. The same group have also reported VacA type i1 to be associated with duodenal ulcer disease, not just gastric cancer in a larger sample, though the association with ulcer disease was weaker than with cancer [42]. In contrast, Ogiwasa and colleagues were unable to confirm the $v a c A$ i as a virulence determinant in 314 strains isolated from East Asia and Southeast Asia where gastric cancer is highly prevalent. [64]

VacA has been reported to produce multiple structural and functional alterations in epithelial cells. VacA disrupts endosomal maturation resulting in vacuolation $[65 ; 66]$, selectively increase the permeability of polarized epithelial cell monolayers leading to barrier dysfunction at tight junctions [67] and also induces mitochondrial damage, cytochrome c release and gastric epithelial cell apoptosis $[68 ; 69 ; 70]$. Recent studies have also demonstrated multiple effects of VacA on the immune system. For example, VacA can interfere with phagocytosis and antigen presentation $[71 ; 72 ; 73]$ and decrease the activation of Jurkat $\mathrm{T}$ cells through inhibiting the activation of NFAT, a key transcription factor required for the expression of genes involved in $\mathrm{T}$ cell activation [74]. VacA can also inhibit $\mathrm{T}$ cell proliferation through mechanisms independent of NFAT activation or IL-2 expression [75;76]. This effect requires an intact Nterminal hydrophobic region of VacA [75] and the T cell by $\beta 2$ integrin [77]. These effects of 
VacA on the immune system might explain how $H$. pylori can evade the adaptive immune response to establish persistent infection. However, as for much of the CagA literature, it remains to be determined whether the above effects of VacA that have been so carefully investigated in vitro also occur during chronic $H$. pylori infection in humans in vivo, and therefore whether they might be clinically relevant.

\section{Adherence}

Adherence is important for $H$. pylori virulence. The intimate attachment observed between $H$. pylori and gastric epithelial cells may facilitate $H$. pylori colonization and efficient delivery of virulence factors such as VacA or CagA into host cells. Functional receptors for $\mathrm{H}$. pylori adherence include fucosylated ABO blood group Lewis b antigens [78;79] and sialyl-Lewis $\mathrm{x} /$ a antigens [80]. The blood group antigen binding adhesin (BabA), a 78-kDa outer membrane protein, encoded by the $b a b A 2$ gene, binds to Lewis $\mathrm{b}$ antigens and $\mathrm{ABO}$ antigen $[78 ; 81 ; 82]$, and the sialic acid binding adhesin (SabA) binds to the sialyl-Lewis x/a antigen [80]. There are two distinct babA alleles ( $b a b A l$ and $b a b A 2$ ) and one highly homologous gene, $b a b B$ [81], but only the babA2 allele is functionally active. The only difference between $b a b A l$ and $b a b A 2$ is that the former lacks a 10-bp insertion, encoding a signal peptide, that results in the $b a b A I$ gene being silent [81]. The $b a b B$ gene is highly homologous to $b a b A$ at its $5^{\prime}$ and $3^{\prime}$ ends but not at the central region that (in $b a b A$ ) determines the specificity of receptor binding. $H$. pylori alters expression of its adhesins during infection. The expression of the $b a b A$ gene can be modulated (switched from "on to off" or from "off to on") through a recombination event (gene conversion) between $b a b A$ and $b a b B$ or by slipped strand mispairing (phase variation) based on the number of CT dinucleotide repeats in the 5 ' region during infection $[79 ; 83 ; 84$; 85]. SabA expression is regulated similarly.

The adherence of $H$. pylori to gastric epthelial cells mediated by BabA facilitates colinization, induces mucosal inflammation and promotes expression of sialyl-Lewis $x / a$ [86;87]. The presence of babA, cagA and vacAsl together ("triple-positive strains") is associated with duodenal ulcer and gastric adenocarcinoma in Western populations [17].

The intimate adherence mediated by SabA may enhance inflammatory response and facilitate the utilization of nutrients exudated from damaged host cells. Once the host inflammatory responses become too strong, the expression of SabA may be switched off, allowing the bacteria to escape from intimate contact with the inflamed epithelium, ensuring long-term persistence of the infection [80].

In addition, SabA was found to mediate binding of $H$. pylori to sialylated structures on neutrophils (which is a prerequisite for their nonopsonic activation [88]) and also to erythrocytes [89]. However, the pathophysiological importance of these latter findings is uncertain and clinicoepidemiological evidence linking SabA to gastric cancer is currently lacking.

\section{Duodenal ulcer promoting gene (DupA)}

Recent studies have reported that a duodenal ulcer-promoting gene ( $d u p A)$, located in the "plasticity region" of the H. pylori genome, may be a novel virulence marker. Analyzing 500 H. pylori strains isolated from patients in Colombia, South Korea, and Japan, Lu et al reported that infection with $d u p A$-positive strains was significantly associated with duodenal ulceration but negatively associated with gastric cancer [90]. Although others have not confirmed these findings regarding $d u p A$ these findings are particularly intriguing given that other proposed H. pylori virulence genes have been associated with both ulcer disease and gastric cancer, whereas patients with duodenal ulcers are paradoxically at decreased risk of gastric cancer [91]. 


\section{Conclusions}

The hunt for $H$. pylori factors that are correlated with specific disease status has identified several positive virulence-associated genetic loci and resulted in the extensive investigation of their effects, largely using co-culture models in vitro. Clinical studies and animal models have demonstrated that some of these factors, especially the cag PAI and the VacA polymorphisms, may be determinants of gastric cancer development in vivo. However, there remains a considerable gap in knowledge between the detailed dissection of the events observed in coculture and clinico-epidemiological confirmation of their role in the pathogenesis of human diseases. Analysis of the association of $\mathrm{H}$. pylori virulence factors with $\mathrm{H}$. pylori-related outcome, particularly gastric cancer, has highlighted the need to consider the geographical contributions to disease outcome. For example, in Western countries, the presence of CagA is associated with an increased risk of severe disease outcome [17;19]. However, in East Asian populations, even though East Asian CagA is more potent biologically its presence is not indicative of increased risk of $\mathrm{H}$. pylori-related diseases [92;93]. Further studies will need to consider other environmental cofactors as well as the genetic diversity of specific Eastern and Western populations and how this might relate to the different outcomes of $H$. pylori infection. For example, host polymorphisms in several genes that regulate inflammatory responses, such as the genes encoding interleukin-1 beta and the interleukin-1 receptor-antagonist, have been found to be associated with the development of gastric cancer [94;95] in Western populations though they appear less important in other regions of the world [96]. While the mechanisms of $H$. pylori-associated gastric carcinogenesis are still relatively poorly defined, their future elucidation may provide opportunities to develop effective strategies for gastric cancer prevention and therapy.

\section{Acknowledgement}

Research support from National Institutes of Health, United States (R01 CA111533 and R21 CA125126).

\section{References}

1. Talley NJ, Fock KM, Moayyedi P. Gastric Cancer Consensus conference recommends Helicobacter pylori screening and treatment in asymptomatic persons from high-risk populations to prevent gastric cancer. Am J Gastroenterol 2008;103:510-514. [PubMed: 18341483]

2. Parkin DM, Bray F, Ferlay J, Pisani P. Global cancer statistics, 2002. CA Cancer J Clin 2005;55:74108. [PubMed: 15761078]

3. Ferlay J, Autier P, Boniol M, Heanue M, Colombet M, Boyle P. Estimates of the cancer incidence and mortality in Europe in 2006. Ann Oncol 2007;18:581-592. [PubMed: 17287242]

4. Uemura N, Okamoto S, Yamamoto S, Matsumura N, Yamaguchi S, Yamakido M, Taniyama K, Sasaki N, Schlemper RJ. Helicobacter pylori infection and the development of gastric cancer. N Engl J Med 2001;345:784-789. [PubMed: 11556297]

5. Parkin DM. The global health burden of infection-associated cancers in the year 2002. Int J Cancer 2006;118:3030-3044. [PubMed: 16404738]

6. Amieva MR, El-Omar EM. Host-bacterial interactions in Helicobacter pylori infection. Gastroenterology 2008;134:306-323. [PubMed: 18166359]

7. Forman D, Burley VJ. Gastric cancer: global pattern of the disease and an overview of environmental risk factors. Best Pract Res Clin Gastroenterol 2006;20:633-649. [PubMed: 16997150]

8. Linz B, Balloux F, Moodley Y, Manica A, Liu H, Roumagnac P, Falush D, Stamer C, Prugnolle F, van der Merwe SW, Yamaoka Y, Graham DY, Perez-Trallero E, Wadstrom T, Suerbaum S, Achtman M. An African origin for the intimate association between humans and Helicobacter pylori. Nature 2007;445:915-918. [PubMed: 17287725]

9. Lu H, Yamaoka Y, Graham DY. Helicobacter pylori virulence factors: facts and fantasies. Curr Opin Gastroenterol 2005;21:653-659. [PubMed: 16220040] 
10. Tomb JF, White O, Kerlavage AR, Clayton RA, Sutton GG, Fleischmann RD, Ketchum KA, Klenk HP, Gill S, Dougherty BA, Nelson K, Quackenbush J, Zhou L, Kirkness EF, Peterson S, Loftus B, Richardson D, Dodson R, Khalak HG, Glodek A, McKenney K, Fitzegerald LM, Lee N, Adams MD, Hickey EK, Berg DE, Gocayne JD, Utterback TR, Peterson JD, Kelley JM, Cotton MD, Weidman JM, Fujii C, Bowman C, Watthey L, Wallin E, Hayes WS, Borodovsky M, Karp PD, Smith HO, Fraser CM, Venter JC. The complete genome sequence of the gastric pathogen Helicobacter pylori. Nature 1997;388:539-547. [PubMed: 9252185]

11. Alm RA, Ling LS, Moir DT, King BL, Brown ED, Doig PC, Smith DR, Noonan B, Guild BC, deJonge BL, Carmel G, Tummino PJ, Caruso A, Uria-Nickelsen M, Mills DM, Ives C, Gibson R, Merberg D, Mills SD, Jiang Q, Taylor DE, Vovis GF, Trust TJ. Genomic-sequence comparison of two unrelated isolates of the human gastric pathogen Helicobacter pylori. Nature 1999;397:176-180. [PubMed: 9923682]

12. Censini S, Lange C, Xiang Z, Crabtree JE, Ghiara P, Borodovsky M, Rappuoli R, Covacci A. cag, a pathogenicity island of Helicobacter pylori, encodes type I-specific and disease-associated virulence factors. Proc Natl Acad Sci U S A 1996;93:14648-14653. [PubMed: 8962108]

13. Covacci A, Telford JL, Del Giudice G, Parsonnet J, Rappuoli R. Helicobacter pylori virulence and genetic geography. Science 1999;284:1328-1333. [PubMed: 10334982]

14. Viala J, Chaput C, Boneca IG, Cardona A, Girardin SE, Moran AP, Athman R, Memet S, Huerre MR, Coyle AJ, DiStefano PS, Sansonetti PJ, Labigne A, Bertin J, Philpott DJ, Ferrero RL. Nod1 responds to peptidoglycan delivered by the Helicobacter pylori cag pathogenicity island. Nat Immunol 2004;5:1166-1174. [PubMed: 15489856]

15. Mizushima T, Sugiyama T, Komatsu Y, Ishizuka J, Kato M, Asaka M. Clinical relevance of the babA2 genotype of Helicobacter pylori in Japanese clinical isolates. J Clin Microbiol 2001;39:2463-2465. [PubMed: 11427555]

16. Blaser MJ, Perez-Perez GI, Kleanthous H, Cover TL, Peek RM, Chyou PH, Stemmermann GN, Nomura A. Infection with Helicobacter pylori strains possessing cagA is associated with an increased risk of developing adenocarcinoma of the stomach. Cancer Res 1995;55:2111-2115. [PubMed: 7743510]

17. Gerhard M, Lehn N, Neumayer N, Boren T, Rad R, Schepp W, Miehlke S, Classen M, Prinz C. Clinical relevance of the Helicobacter pylori gene for blood-group antigen-binding adhesin. Proc Natl Acad Sci U S A 1999;96:12778-12783. [PubMed: 10535999]

18. Parsonnet J, Friedman GD, Orentreich N, Vogelman H. Risk for gastric cancer in people with CagA positive or CagA negative Helicobacter pylori infection. Gut 1997;40:297-301. [PubMed: 9135515]

19. Hamlet A, Thoreson AC, Nilsson O, Svennerholm AM, Olbe L. Duodenal Helicobacter pylori infection differs in cagA genotype between asymptomatic subjects and patients with duodenal ulcers. Gastroenterology 1999;116:259-268. [PubMed: 9922305]

20. Ogura K, Maeda S, Nakao M, Watanabe T, Tada M, Kyutoku T, Yoshida H, Shiratori Y, Omata M. Virulence factors of Helicobacter pylori responsible for gastric diseases in Mongolian gerbil. J Exp Med 2000;192:1601-1610. [PubMed: 11104802]

21. Franco AT, Israel DA, Washington MK, Krishna U, Fox JG, Rogers AB, Neish AS, Collier-Hyams L, Perez-Perez GI, Hatakeyama M, Whitehead R, Gaus K, O'Brien DP, Romero-Gallo J, Peek RM Jr. Activation of beta-catenin by carcinogenic Helicobacter pylori. Proc Natl Acad Sci U S A 2005;102:10646-10651. [PubMed: 16027366]

22. Murata-Kamiya N, Kurashima Y, Teishikata Y, Yamahashi Y, Saito Y, Higashi H, Aburatani H, Akiyama T, Peek RM Jr. Azuma T, Hatakeyama M. Helicobacter pylori CagA interacts with Ecadherin and deregulates the beta-catenin signal that promotes intestinal transdifferentiation in gastric epithelial cells. Oncogene 2007;26:4617-4626. [PubMed: 17237808]

23. Franco AT, Johnston E, Krishna U, Yamaoka Y, Israel DA, Nagy TA, Wroblewski LE, Piazuelo MB, Correa P, Peek RM Jr. Regulation of gastric carcinogenesis by Helicobacter pylori virulence factors. Cancer Res 2008;68:379-387. [PubMed: 18199531]

24. Israel DA, Salama N, Arnold CN, Moss SF, Ando T, Wirth HP, Tham KT, Camorlinga M, Blaser MJ, Falkow S, Peek RM Jr. Helicobacter pylori strainspecific differences in genetic content, identified by microarray, influence host inflammatory responses. J Clin Invest 2001;107:611-620. [PubMed: 11238562] 
25. Ohnishi N, Yuasa H, Tanaka S, Sawa H, Miura M, Matsui A, Higashi H, Musashi M, Iwabuchi K, Suzuki M, Yamada G, Azuma T, Hatakeyama M. Transgenic expression of Helicobacter pylori CagA induces gastrointestinal and hematopoietic neoplasms in mouse. Proc Natl Acad Sci U S A 2008;105:1003-1008. [PubMed: 18192401]

26. Couturier MR, Tasca E, Montecucco C, Stein M. Interaction with CagF is required for translocation of CagA into the host via the Helicobacter pylori type IV secretion system. Infect Immun 2006;74:273-281. [PubMed: 16368981]

27. Pattis I, Weiss E, Laugks R, Haas R, Fischer W. The Helicobacter pylori CagF protein is a type IV secretion chaperone-like molecule that binds close to the C-terminal secretion signal of the CagA effector protein. Microbiology 2007;153:2896-2909. [PubMed: 17768234]

28. Kwok T, Zabler D, Urman S, Rohde M, Hartig R, Wessler S, Misselwitz R, Berger J, Sewald N, Konig W, Backert S. Helicobacter exploits integrin for type IV secretion and kinase activation. Nature 2007;449:862-866. [PubMed: 17943123]

29. Higashi H, Tsutsumi R, Muto S, Sugiyama T, Azuma T, Asaka M, Hatakeyama M. SHP-2 tyrosine phosphatase as an intracellular target of Helicobacter pylori CagA protein. Science 2002;295:683686. [PubMed: 11743164]

30. Selbach M, Moese S, Hauck CR, Meyer TF, Backert S. Src is the kinase of the Helicobacter pylori CagA protein in vitro and in vivo. J Biol Chem 2002;277:6775-6778. [PubMed: 11788577]

31. Stein M, Bagnoli F, Halenbeck R, Rappuoli R, Fantl WJ, Covacci A. c-Src/Lyn kinases activate Helicobacter pylori CagA through tyrosine phosphorylation of the EPIYA motifs. Mol Microbiol 2002;43:971-980. [PubMed: 11929545]

32. Tammer I, Brandt S, Hartig R, Konig W, Backert S. Activation of Abl by Helicobacter pylori: a novel kinase for CagA and crucial mediator of host cell scattering. Gastroenterology 2007;132:1309-1319. [PubMed: 17408661]

33. Poppe M, Feller SM, Romer G, Wessler S. Phosphorylation of Helicobacter pylori CagA by c-Abl leads to cell motility. Oncogene 2007;26:3462-3472. [PubMed: 17160020]

34. Tsutsumi R, Higashi H, Higuchi M, Okada M, Hatakeyama M. Attenuation of Helicobacter pylori CagA x SHP-2 signaling by interaction between CagA and C-terminal Src kinase. J Biol Chem 2003;278:3664-3670. [PubMed: 12446738]

35. Suzuki M, Mimuro H, Suzuki T, Park M, Yamamoto T, Sasakawa C. Interaction of CagA with Crk plays an important role in Helicobacter pylori-induced loss of gastric epithelial cell adhesion. J Exp Med 2005;202:1235-1247. [PubMed: 16275761]

36. Tsutsumi R, Takahashi A, Azuma T, Higashi H, Hatakeyama M. Focal adhesion kinase is a substrate and downstream effector of SHP-2 complexed with Helicobacter pylori CagA. Mol Cell Biol 2006;26:261-276. [PubMed: 16354697]

37. Higashi H, Nakaya A, Tsutsumi R, Yokoyama K, Fujii Y, Ishikawa S, Higuchi M, Takahashi A, Kurashima Y, Teishikata Y, Tanaka S, Azuma T, Hatakeyama M. Helicobacter pylori CagA induces Ras-independent morphogenetic response through SHP-2 recruitment and activation. J Biol Chem 2004;279:17205-17216. [PubMed: 14963045]

38. Naito M, Yamazaki T, Tsutsumi R, Higashi H, Onoe K, Yamazaki S, Azuma T, Hatakeyama M. Influence of EPIYA-repeat polymorphism on the phosphorylation-dependent biological activity of Helicobacter pylori CagA. Gastroenterology 2006;130:1181-1190. [PubMed: 16618412]

39. Higashi H, Yokoyama K, Fujii Y, Ren S, Yuasa H, Saadat I, Murata-Kamiya N, Azuma T, Hatakeyama M. EPIYA motif is a membrane-targeting signal of Helicobacter pylori virulence factor CagA in mammalian cells. J Biol Chem 2005;280:23130-23137. [PubMed: 15831497]

40. Higashi H, Tsutsumi R, Fujita A, Yamazaki S, Asaka M, Azuma T, Hatakeyama M. Biological activity of the Helicobacter pylori virulence factor $\mathrm{CagA}$ is determined by variation in the tyrosine phosphorylation sites. Proc Natl Acad Sci U S A 2002;99:14428-14433. [PubMed: 12391297]

41. Yamaoka Y, Kodama T, Kashima K, Graham DY, Sepulveda AR. Variants of the 3 ' region of the cagA gene in Helicobacter pylori isolates from patients with different $\mathrm{H}$. pylori-associated diseases. J Clin Microbiol 1998;36:2258-2263. [PubMed: 9666002]

42. Basso D, Zambon CF, Letley DP, Stranges A, Marchet A, Rhead JL, Schiavon S, Guariso G, Ceroti M, Nitti D, Rugge M, Plebani M, Atherton JC. Clinical relevance of Helicobacter pylori cagA and vacA gene polymorphisms. Gastroenterology 2008;135:91-99. [PubMed: 18474244] 
43. Amieva MR, Vogelmann R, Covacci A, Tompkins LS, Nelson WJ, Falkow S. Disruption of the epithelial apical-junctional complex by Helicobacter pylori CagA. Science 2003;300:1430-1434. [PubMed: 12775840]

44. Churin Y, Al-Ghoul L, Kepp O, Meyer TF, Birchmeier W, Naumann M. Helicobacter pylori CagA protein targets the c-Met receptor and enhances the motogenic response. J Cell Biol 2003;161:249255. [PubMed: 12719469]

45. Mimuro H, Suzuki T, Tanaka J, Asahi M, Haas R, Sasakawa C. Grb2 is a key mediator of Helicobacter pylori CagA protein activities. Mol Cell 2002;10:745-755. [PubMed: 12419219]

46. Saadat I, Higashi H, Obuse C, Umeda M, Murata-Kamiya N, Saito Y, Lu H, Ohnishi N, Azuma T, Suzuki A, Ohno S, Hatakeyama M. Helicobacter pylori CagA targets PAR1/MARK kinase to disrupt epithelial cell polarity. Nature 2007;447:330-333. [PubMed: 17507984]

47. Zeaiter Z, Cohen D, Musch A, Bagnoli F, Covacci A, Stein M. Analysis of detergent-resistant membranes of Helicobacter pylori infected gastric adenocarcinoma cells reveals a role for MARK2/ Par1b in CagA-mediated disruption of cellular polarity. Cell Microbiol 2008;10:781-794. [PubMed: 18005242]

48. Bagnoli F, Buti L, Tompkins L, Covacci A, Amieva MR. Helicobacter pylori CagA induces a transition from polarized to invasive phenotypes in MDCK cells. Proc Natl Acad Sci U S A 2005;102:16339-16344. [PubMed: 16258069]

49. Crabtree JE, Xiang Z, Lindley IJ, Tompkins DS, Rappuoli R, Covacci A. Induction of interleukin-8 secretion from gastric epithelial cells by a cagA negative isogenic mutant of Helicobacter pylori. $\mathrm{J}$ Clin Pathol 1995;48:967-969. [PubMed: 8537502]

50. Fischer W, Puls J, Buhrdorf R, Gebert B, Odenbreit S, Haas R. Systematic mutagenesis of the Helicobacter pylori cag pathogenicity island: essential genes for CagA translocation in host cells and induction of interleukin-8. Mol Microbiol 2001;42:1337-1348. [PubMed: 11886563]

51. Brandt S, Kwok T, Hartig R, Konig W, Backert S. NF-kappaB activation and potentiation of proinflammatory responses by the Helicobacter pylori CagA protein. Proc Natl Acad Sci U S A 2005;102:9300-9305. [PubMed: 15972330]

52. Yokoyama K, Higashi H, Ishikawa S, Fujii Y, Kondo S, Kato H, Azuma T, Wada A, Hirayama T, Aburatani H, Hatakeyama M. Functional antagonism between Helicobacter pylori CagA and vacuolating toxin VacA in control of the NFAT signaling pathway in gastric epithelial cells. Proc Natl Acad Sci U S A 2005;102:9661-9666. [PubMed: 15980153]

53. Telford JL, Ghiara P, Dell'Orco M, Comanducci M, Burroni D, Bugnoli M, Tecce MF, Censini S, Covacci A, Xiang Z, et al. Gene structure of the Helicobacter pylori cytotoxin and evidence of its key role in gastric disease. J Exp Med 1994;179:1653-1658. [PubMed: 8163943]

54. Cover TL, Blaser MJ. Purification and characterization of the vacuolating toxin from Helicobacter pylori. J Biol Chem 1992;267:10570-10575. [PubMed: 1587837]

55. Ilver D, Barone S, Mercati D, Lupetti P, Telford JL. Helicobacter pylori toxin VacA is transferred to host cells via a novel contact-dependent mechanism. Cell Microbiol 2004;6:167-174. [PubMed: 14706102]

56. Cover TL, Blanke SR. Helicobacter pylori VacA, a paradigm for toxin multifunctionality. Nat Rev Microbiol 2005;3:320-332. [PubMed: 15759043]

57. Atherton JC, Cao P, Peek RM Jr. Tummuru MK, Blaser MJ, Cover TL. Mosaicism in vacuolating cytotoxin alleles of Helicobacter pylori. Association of specific vacA types with cytotoxin production and peptic ulceration. J Biol Chem 1995;270:17771-17777. [PubMed: 7629077]

58. McClain MS, Cao P, Iwamoto H, Vinion-Dubiel AD, Szabo G, Shao Z, Cover TL. A 12-amino-acid segment, present in type s2 but not type s1 Helicobacter pylori VacA proteins, abolishes cytotoxin activity and alters membrane channel formation. J Bacteriol 2001;183:6499-6508. [PubMed: 11673417]

59. Pagliaccia C, de Bernard M, Lupetti P, Ji X, Burroni D, Cover TL, Papini E, Rappuoli R, Telford JL, Reyrat JM. The $\mathrm{m} 2$ form of the Helicobacter pylori cytotoxin has cell type-specific vacuolating activity. Proc Natl Acad Sci U S A 1998;95:10212-10217. [PubMed: 9707626]

60. Ji X, Fernandez T, Burroni D, Pagliaccia C, Atherton JC, Reyrat JM, Rappuoli R, Telford JL. Cell specificity of Helicobacter pylori cytotoxin is determined by a short region in the polymorphic midregion. Infect Immun 2000;68:3754-3757. [PubMed: 10816542] 
61. Atherton JC, Peek RM Jr. Tham KT, Cover TL, Blaser MJ. Clinical and pathological importance of heterogeneity in vacA, the vacuolating cytotoxin gene of Helicobacter pylori. Gastroenterology 1997;112:92-99. [PubMed: 8978347]

62. Miehlke S, Kirsch C, Agha-Amiri K, Gunther T, Lehn N, Malfertheiner P, Stolte M, Ehninger G, Bayerdorffer E. The Helicobacter pylori vacA s1, $\mathrm{m} 1$ genotype and cagA is associated with gastric carcinoma in Germany. Int J Cancer 2000;87:322-327. [PubMed: 10897035]

63. Rhead JL, Letley DP, Mohammadi M, Hussein N, Mohagheghi MA, Eshagh Hosseini M, Atherton JC. A new Helicobacter pylori vacuolating cytotoxin determinant, the intermediate region, is associated with gastric cancer. Gastroenterology 2007;133:926-936. [PubMed: 17854597]

64. Ogiwara H, Graham DY, Yamaoka Y. vacA i-region subtyping. Gastroenterology 2008;134:1267. [PubMed: 18395110]author reply 1268

65. Leunk RD, Johnson PT, David BC, Kraft WG, Morgan DR. Cytotoxic activity in broth-culture filtrates of Campylobacter pylori. J Med Microbiol 1988;26:93-99. [PubMed: 3385767]

66. Papini E, de Bernard M, Milia E, Bugnoli M, Zerial M, Rappuoli R, Montecucco C. Cellular vacuoles induced by Helicobacter pylori originate from late endosomal compartments. Proc Natl Acad Sci U S A 1994;91:9720-9724. [PubMed: 7937879]

67. Papini E, Satin B, Norais N, de Bernard M, Telford JL, Rappuoli R, Montecucco C. Selective increase of the permeability of polarized epithelial cell monolayers by Helicobacter pylori vacuolating toxin. J Clin Invest 1998;102:813-820. [PubMed: 9710450]

68. Galmiche A, Rassow J, Doye A, Cagnol S, Chambard JC, Contamin S, de Thillot V, Just I, Ricci V, Solcia E, Van Obberghen E, Boquet P. The N-terminal $34 \mathrm{kDa}$ fragment of Helicobacter pylori vacuolating cytotoxin targets mitochondria and induces cytochrome c release. Embo J 2000;19:63616370. [PubMed: 11101509]

69. Cover TL, Krishna US, Israel DA, Peek RM Jr. Induction of gastric epithelial cell apoptosis by Helicobacter pylori vacuolating cytotoxin. Cancer Res 2003;63:951-957. [PubMed: 12615708]

70. Manente L, Perna A, Buommino E, Altucci L, Lucariello A, Citro G, Baldi A, Iaquinto G, Tufano MA, De Luca A. The Helicobacter pylori's protein VacA has direct effects on the regulation of cell cycle and apoptosis in gastric epithelial cells. J Cell Physiol 2008;214:582-587. [PubMed: 17786942]

71. Molinari M, Salio M, Galli C, Norais N, Rappuoli R, Lanzavecchia A, Montecucco C. Selective inhibition of Ii-dependent antigen presentation by Helicobacter pylori toxin VacA. J Exp Med 1998;187:135-140. [PubMed: 9419220]

72. Allen LA, Schlesinger LS, Kang B. Virulent strains of Helicobacter pylori demonstrate delayed phagocytosis and stimulate homotypic phagosome fusion in macrophages. J Exp Med 2000;191:115128. [PubMed: 10620610]

73. Zheng PY, Jones NL. Helicobacter pylori strains expressing the vacuolating cytotoxin interrupt phagosome maturation in macrophages by recruiting and retaining TACO (coronin 1) protein. Cell Microbiol 2003;5:25-40. [PubMed: 12542468]

74. Gebert B, Fischer W, Weiss E, Hoffmann R, Haas R. Helicobacter pylori vacuolating cytotoxin inhibits T lymphocyte activation. Science 2003;301:1099-1102. [PubMed: 12934009]

75. Sundrud MS, Torres VJ, Unutmaz D, Cover TL. Inhibition of primary human T cell proliferation by Helicobacter pylori vacuolating toxin (VacA) is independent of VacA effects on IL-2 secretion. Proc Natl Acad Sci U S A 2004;101:7727-7732. [PubMed: 15128946]

76. Torres VJ, VanCompernolle SE, Sundrud MS, Unutmaz D, Cover TL. Helicobacter pylori vacuolating cytotoxin inhibits activation-induced proliferation of human $\mathrm{T}$ and B lymphocyte subsets. J Immunol 2007;179:5433-5440. [PubMed: 17911630]

77. Sewald X, Gebert-Vogl B, Prassl S, Barwig I, Weiss E, Fabbri M, Osicka R, Schiemann M, Busch DH, Semmrich M, Holzmann B, Sebo P, Haas R. Integrin subunit CD18 Is the T-lymphocyte receptor for the Helicobacter pylori vacuolating cytotoxin. Cell Host Microbe 2008;3:20-29. [PubMed: 18191791]

78. Boren T, Falk P, Roth KA, Larson G, Normark S. Attachment of Helicobacter pylori to human gastric epithelium mediated by blood group antigens. Science 1993;262:1892-1895. [PubMed: 8018146]

79. Aspholm-Hurtig M, Dailide G, Lahmann M, Kalia A, Ilver D, Roche N, Vikstrom S, Sjostrom R, Linden S, Backstrom A, Lundberg C, Arnqvist A, Mahdavi J, Nilsson UJ, Velapatino B, Gilman RH, Gerhard M, Alarcon T, Lopez-Brea M, Nakazawa T, Fox JG, Correa P, Dominguez-Bello MG, Perez- 
Perez GI, Blaser MJ, Normark S, Carlstedt I, Oscarson S, Teneberg S, Berg DE, Boren T. Functional adaptation of BabA, the H. pylori ABO blood group antigen binding adhesin. Science 2004;305:519522. [PubMed: 15273394]

80. Mahdavi J, Sonden B, Hurtig M, Olfat FO, Forsberg L, Roche N, Angstrom J, Larsson T, Teneberg S, Karlsson KA, Altraja S, Wadstrom T, Kersulyte D, Berg DE, Dubois A, Petersson C, Magnusson KE, Norberg T, Lindh F, Lundskog BB, Arnqvist A, Hammarstrom L, Boren T. Helicobacter pylori SabA adhesin in persistent infection and chronic inflammation. Science 2002;297:573-578. [PubMed: 12142529]

81. Ilver D, Arnqvist A, Ogren J, Frick IM, Kersulyte D, Incecik ET, Berg DE, Covacci A, Engstrand L, Boren T. Helicobacter pylori adhesin binding fucosylated histo-blood group antigens revealed by retagging. Science 1998;279:373-377. [PubMed: 9430586]

82. Boren T, Normark S, Falk P. Helicobacter pylori: molecular basis for host recognition and bacterial adherence. Trends Microbiol 1994;2:221-228. [PubMed: 8081648]

83. Colbeck JC, Hansen LM, Fong JM, Solnick JV. Genotypic profile of the outer membrane proteins BabA and BabB in clinical isolates of Helicobacter pylori. Infect Immun 2006;74:4375-4378. [PubMed: 16790815]

84. Solnick JV, Hansen LM, Salama NR, Boonjakuakul JK, Syvanen M. Modification of Helicobacter pylori outer membrane protein expression during experimental infection of rhesus macaques. Proc Natl Acad Sci U S A 2004;101:2106-2111. [PubMed: 14762173]

85. Backstrom A, Lundberg C, Kersulyte D, Berg DE, Boren T, Arnqvist A. Metastability of Helicobacter pylori bab adhesin genes and dynamics in Lewis b antigen binding. Proc Natl Acad Sci U S A 2004;101:16923-16928. [PubMed: 15557006]

86. Prinz C, Schoniger M, Rad R, Becker I, Keiditsch E, Wagenpfeil S, Classen M, Rosch T, Schepp W, Gerhard M. Key importance of the Helicobacter pylori adherence factor blood group antigen binding adhesin during chronic gastric inflammation. Cancer Res 2001;61:1903-1909. [PubMed: 11280745]

87. Rad R, Gerhard M, Lang R, Schoniger M, Rosch T, Schepp W, Becker I, Wagner H, Prinz C. The Helicobacter pylori blood group antigen-binding adhesin facilitates bacterial colonization and augments a nonspecific immune response. J Immunol 2002;168:3033-3041. [PubMed: 11884476]

88. Unemo M, Aspholm-Hurtig M, Ilver D, Bergstrom J, Boren T, Danielsson D, Teneberg S. The sialic acid binding SabA adhesin of Helicobacter pylori is essential for nonopsonic activation of human neutrophils. J Biol Chem 2005;280:15390-15397. [PubMed: 15689619]

89. Aspholm M, Olfat FO, Norden J, Sonden B, Lundberg C, Sjostrom R, Altraja S, Odenbreit S, Haas R, Wadstrom T, Engstrand L, Semino-Mora C, Liu H, Dubois A, Teneberg S, Arnqvist A, Boren T. $\mathrm{SabA}$ is the $\mathrm{H}$. pylori hemagglutinin and is polymorphic in binding to sialylated glycans. PLoS Pathog 2006;2:e110. [PubMed: 17121461]

90. Lu H, Hsu PI, Graham DY, Yamaoka Y. Duodenal ulcer promoting gene of Helicobacter pylori. Gastroenterology 2005;128:833-848. [PubMed: 15825067]

91. Hansson LE, Nyren O, Hsing AW, Bergstrom R, Josefsson S, Chow WH, Fraumeni JF Jr. Adami HO. The risk of stomach cancer in patients with gastric or duodenal ulcer disease. N Engl J Med 1996;335:242-249. [PubMed: 8657240]

92. Pan ZJ, van der Hulst RW, Feller M, Xiao SD, Tytgat GN, Dankert J, van der Ende A. Equally high prevalences of infection with cagA-positive Helicobacter pylori in Chinese patients with peptic ulcer disease and those with chronic gastritis-associated dyspepsia. J Clin Microbiol 1997;35:1344-1347. [PubMed: 9163441]

93. Azuma T, Yamazaki S, Yamakawa A, Ohtani M, Muramatsu A, Suto H, Ito Y, Dojo M, Yamazaki Y, Kuriyama M, Keida Y, Higashi H, Hatakeyama M. Association between diversity in the Src homology 2 domain--containing tyrosine phosphatase binding site of Helicobacter pylori CagA protein and gastric atrophy and cancer. J Infect Dis 2004;189:820-827. [PubMed: 14976598]

94. El-Omar EM, Carrington M, Chow WH, McColl KE, Bream JH, Young HA, Herrera J, Lissowska J, Yuan CC, Rothman N, Lanyon G, Martin M, Fraumeni JF Jr. Rabkin CS. Interleukin-1 polymorphisms associated with increased risk of gastric cancer. Nature 2000;404:398-402. [PubMed: 10746728]

95. Machado JC, Pharoah P, Sousa S, Carvalho R, Oliveira C, Figueiredo C, Amorim A, Seruca R, Caldas C, Carneiro F, Sobrinho-Simoes M. Interleukin 1B and interleukin 1RN polymorphisms are 
associated with increased risk of gastric carcinoma. Gastroenterology 2001;121:823-829. [PubMed: 11606496]

96. Kamangar F, Cheng C, Abnet CC, Rabkin CS. Interleukin-1B polymorphisms and gastric cancer risk--a meta-analysis. Cancer Epidemiol Biomarkers Prev 2006;15:1920-1928. [PubMed: 17035400] 


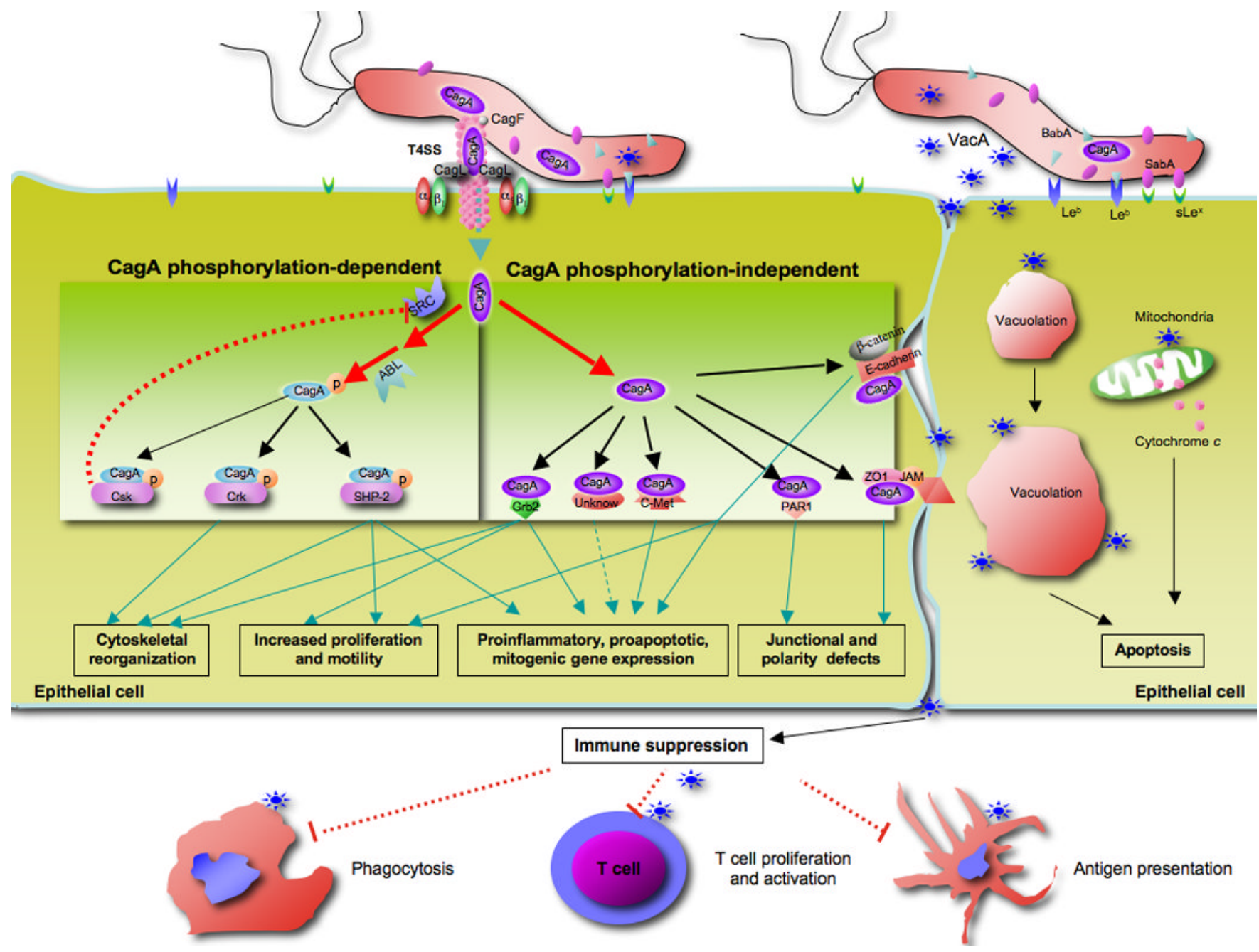

1.

The pathogenesis of $H$. pylori infection. Virulence factors such as CagA, genes within the $c a g$ PAI, VacA, BabA and SabA are involved in numerous host cell effects. H. pylori adherence to gastric epithelial cells is mediated by BabA and SabA binding Lewis ${ }^{\mathrm{b}}$, and Lewis ${ }^{\mathrm{x} / \mathrm{a}}$ respectively, thus facilitating $H$. pylori colonization and the efficient delivery of virulence factors to host cells. Following the attachment of $H$. pylori to gastric epithelial cell, the CagA protein is delivered into gastric epithelial cells through the $H$. pylori type 4 secretion system (T4SS). There, CagA may be tyrosine phosphorylated at EPIYA sites initially by SRC and in more sustained fashioned by ABL kinases. CagA can interact with intracellular proteins and deregulate distinct signaling pathways through both tyrosine phosphorylation-dependent or independent mechanisms. The pathobiological effects including cell elongation (producing cell scattering and the "hummingbird" phenotype), disruption of intercellular junctions, loss of cell polarity, the promotion of inflammation and dysregulation of proliferation and apoptosis. The effects of VacA on host cells include induction of cytoplasmic vacuolation, mitochondrial damage, cytochrome $c$ release, apoptosis and immune evasion. Many of these events may contribute to gastric carcinoma development. 